\title{
The effects of different pre-treatments on the physicochemical composition and sensory acceptability of 'Kacang Koro' energy bar
}

\author{
${ }^{1}$ Wan Mohamad Din, W.N.I., ${ }^{1}$ Mohd Zin, Z., ${ }^{2}$ Abdullah, M.A.A. and ${ }^{1, *}$ Zainol, M.K. \\ ${ }^{1}$ Faculty of Fisheries and Food Science, Universiti Malaysia Terengganu, 21030, Kuala Nerus, \\ Terengganu, Malaysia \\ ${ }^{2}$ Faculty of Science and Marine Environment, Universiti Malaysia Terengganu, 21030, Kuala Nerus, \\ Terengganu, Malaysia
}

\begin{abstract}
Article history:
Received: 31 January 2020

Received in revised form: 14

March 2020

Accepted: 22 March 2020

Available Online: 5 April

2020
\end{abstract}

Keywords:

Pre-treatments,

'Kacang Koro' (Canavalia ensiformis),

Energy bar

DOI:

https://doi.org/10.26656/fr.2017.4(4).042

\begin{abstract}
Every good food comes with its negative side, and 'Kacang Koro' is one of them. Although 'Kacang Koro' contains a lot of protein, it also has a negative side, such as an anti-nutritional factor. These anti-nutrient factors need to be removed in order to produce nutritious food. This study was aimed to determine the effect of pre-treatment (soaking, soaking-boiling, soaking-roasting, soaking-microwave) on physicochemical composition and sensory acceptability in 'Kacang Koro' energy bar. The energy bars were subjected to physical analyses, proximate analysis, calorie content, phytochemical analyses and sensory analysis. All the different treatments of 'Kacang Koro' energy bar showed moisture content of $8.29-12.42 \%$, ash of $1.09-1.11 \%$, crude protein of $7.51-10.14 \%$, crude fat of $12.75-17.77 \%$, crude fibre of $2.78-3.62 \%$, and carbohydrate of 57.19 $63.91 \%$. The calorie content was found to be $484.81-511.29 \mathrm{kcal} / 100 \mathrm{~g}$. The oxalate content in all 'Kacang Koro' pre-treated is ranged between $29.81-45.1 \mathrm{mg} / \mathrm{kg}$. The phytic acid content is between $0.15 \%-0.37 \%$ and the tannin content is in the range of $25.53 \mathrm{~L}$ $52.30 \mathrm{mg} \mathrm{GAE} / \mathrm{L}$. Energy bar with soaking-microwave pretreated 'Kacang Koro' has higher value in crude protein, crude fat, and crude fibre but moderate in moisture and carbohydrate content, meanwhile lower in ash content. Sensory acceptability tests showed the sweetness, taste and overall acceptability of the samples were significantly different between 'Kacang Koro' energy bars using soaking compared to soaking-microwave pretreatment. The pre-treatment of 'Kacang Koro' may boost the use of these 'Kacang Koro' in the food industry and promote their application.
\end{abstract}

\section{Introduction}

'Kacang Koro' or Jack Bean (Canavalia ensiformis) is native to Central America and West Indies, but it has been widely cultivated in the humid tropics of Africa and Asia (Uadia, 2017). This plant is an annual perennial climbing that has a strong root system and is able to grow up to $2 \mathrm{~m}$ high. The young pods and green seeds of 'Kacang Koro' can be eaten as vegetables, and sometimes, the seeds are also used as a coffee substitute, and the mature seed of 'Kacang Koro' is mostly used as animal feed. 'Kacang Koro' is considered as underutilized legume as it is rarely used for human consumption because it requires more processing techniques before it can be consumed (Karoli et al., 2017).

Often, every good food comes with its negative side and 'Kacang Koro' is one of them. Although 'Kacang Koro' contains plenty of protein, it also has a negative side, such as an anti-nutritional factor. Anti-nutritional factor is substances that are generated in natural feedstuffs through normal metabolism which when ingested, can compromise optimum nutrition through mechanisms such as nutrient inactivation, it can also interfere with the digestive process, and metabolic feed utilization (Betancur-Ancona et al., 2012). Antinutritional factors (ANFs) in most legumes such as in 'Kacang Koro' make them forbidden to be eaten raw. Some of the anti-nutritional factors that contain in 'Kacang Koro' include protease inhibitors, lectins, saponins, and tannins (Eke et al., 2007) and thus, excessive consumption should be avoided.

The nutritive value of legumes depends on their processing pre-treatments, presence or absence of 
antinutritional or toxic factors and possible interaction of nutrients with other food components (Ghadge et al., 2008). It is also essential to remove or reduce the antinutritional factors in order to improve the nutritional quality and also to provide effective utilization of legumes (Akande and Fabiyi, 2010). These processing pre-treatments will make legume seeds more edible and eliminate or inactivate the toxic factors contained in many of them (Betancur-Ancona et al., 2012). Akande and Fabiyi (2010) and Abbas and Ahmad (2018) stated that processing techniques or treatments such as soaking, cooking, toasting, autoclaving, microwave cooking, pressure cooking, germination, and chemical treatment can be used to inactivate the ANFs and it also can improve the quality of legumes.

An energy bar is one of the foods that started out in space projects snack that provides both energy and nutrition for an astronaut (Narang, 2017). Nowadays, energy bars are consumed by athletes and other physically active people as it provides the energy and vitality needed to sustain physical and mental activities. Thus, it contains high carbohydrates but moderate in protein to meet the caloric demands (Uma et al., 2018). However, energy bars are also consumed by ordinary people or not physically active people because it offers a fast, convenient food source that requires no preparation, higher shelf life and does not need refrigerated storage (Gir and Mridula, 2016). The most popular sources of protein from energy bars are soy and dairy, and it also comes with other protein sources such as peanut butter, nuts, to improve their protein content (Aldrich, 2015).

The development of the new product based on underutilized legumes such as 'Kacang Koro' could maximize the utilization of 'Kacang Koro' in the form of energy bar hence promoting local farmers to increase the production for commercial purposes (Maphosa and Jideani, 2017). Therefore, the purpose of this research was to determine the effect of pre-treatment on the physicochemical properties of the 'Kacang Koro' energy bar and also to determine the effect of pre-treatment on sensory acceptability of 'Kacang Koro' energy bar.

\section{Materials and methods}

'Kacang Koro' seeds were obtained from Kuala Berang, Terengganu. The other ingredients for making the energy bar such as almond, cashew, rolled oat, raisin, honey, butter, and brown sugar were obtained from the local supermarket.

\subsection{Pretreatment of 'Kacang Koro'}

'Kacang Koro' was treated with four different pretreatments namely soaking, soaking-boiling, soaking- roasting and soaking-microwave. All 'Kacang Koro' was first immersed in the water of the tap at room temperature for $48 \mathrm{hrs}$ and the water was changed 5 times. The ratio of 'Kacang Koro' and water is 1:5, respectively and the seeds were de-hulled. The second pre-treatment which is boiling, 'Kacang Koro' was boiled for $30 \mathrm{mins}$ at $100^{\circ} \mathrm{C}$. In the roasting pretreatment, 'Kacang Koro' was roasted in the convection oven at $150^{\circ} \mathrm{C}$ for 30 mins. The last treatment pretreatment was microwave which required 5 mins in the microwave using the frequency $2450 \mathrm{MHz}$.

\subsection{Development of 'Kacang Koro' energy bar}

'Kacang Koro' energy bars were prepared based on the formulation shown in Table 1. Almond, cashew, and rolled oat were roasted at $175^{\circ} \mathrm{C}$ in the convection oven for 15 mins prior to the preparation of the energy bar. All the chopped nuts (uniformly chopped) and pre-treated 'Kacang Koro' were then mixed with the rolled oats and nuts mixture. Butter, honey and brown sugar were mixed together on the non-stick pan over slow-heat until it completely dissolved. Then, the rolled oat and nuts mixture was added into the pan and mixed well for 3 min. The energy bars were then weighed $20 \mathrm{~g}$ each and then pressed into the mould, baked at $140^{\circ} \mathrm{C}$ for 10 mins and then stored in the freezer for about 30 mins. After the unmoulding process, the energy bars were stored in the chiller to control its shelf life.

Table 1. Formulation for 'Kacang Koro' energy bar (KKEB)

\begin{tabular}{cc}
\hline Ingredients & Percentage $(\%)$ \\
\hline 'Kacang Koro' & 15 \\
Almond & 9 \\
Cashew & 9 \\
Rolled oat & 20 \\
Raisin & 10 \\
Honey & 10 \\
Butter & 12 \\
Brown sugar & 15 \\
Total & 100 \\
\hline
\end{tabular}

\subsection{Physical analyses}

\subsubsection{Sample $\mathrm{pH}$ analysis}

The samples were prepared by blended finely and homogenized $5 \mathrm{~g}$ of samples with $20 \mathrm{~mL}$ of distilled water. Prior to analysis, $\mathrm{pH}$ meter was calibrated with standard buffer solutions of $\mathrm{pH} 7.0$ and $\mathrm{pH}$ 4.0. Then, the $\mathrm{pH}$ value was recorded.

\subsubsection{Colour profile analysis}

Colour ( $\mathrm{L}^{*}, \mathrm{a}^{*}$, and $\mathrm{b}^{*}$ values) of the samples were determined using Colourimeter (Minolta Chroma CR 300, Japan). Colour was measured by spectrophotometer (trismulus colour machine with CIE lab colour scale) 
(Hunter, Lab Scan X E, Reston VA). The sample was crushed coarsely and flattened prior to colour determination.

\subsubsection{Texture profile analysis}

A double arm texture analyser was used (TA.HD plus) to analyse the texture of the energy bar, the probe used was HDP/BSW; blade set with warner bratzler. Sample was subjected to post-test speed $(10 \mathrm{~mm} / \mathrm{sec})$, with test speed $(2 \mathrm{~mm} / \mathrm{sec})$, and the distance was $25 \mathrm{~mm}$, having a load cell of $100 \mathrm{~kg}$. The texture of the energy bars was measured according to their hardness.

\subsection{Chemical analyses}

\subsubsection{Proximate analysis}

The method of AOAC (2007) was used for the determination of moisture, ash, crude protein, crude fat, crude fibre, and carbohydrate content.

\subsubsection{Determination of calorie content}

Bomb calorimeter was used to determine the calorie content of the 'Kacang Koro' energy bar. The sample was weighed $(1 \mathrm{~g})$, and placed in the crucible. Then the crucible was placed in its container, $10 \mathrm{~cm}$ of fuse wire was inserted in its slot, and the wire was formed as ' $U$ '. The bomb charger was attached and the fill switch was pressed and the oxygen was filled until the pressure reached 420 PSI. The bomb was then inserted into the bomb bucket, followed by filling the tank with $2000 \mathrm{~mL}$ of water. Next, the bomb bucket was placed inside the bomb bucket well and the lid was closed. The analysis started and the heat of combustion (cal/g) was recorded after inserting the length of the remaining fuse wire.

\subsubsection{Determination of oxalate content}

One gram of pulverized sample was weighed and 75 $\mathrm{mL}$ of $3 \mathrm{M}$ sulphuric acid was added and stirred for an hour. Then, $25 \mathrm{~mL}$ aliquot of the filtrate was collected and heated to $80-90^{\circ} \mathrm{C}$. The filtrate was kept above $70^{\circ}$ $\mathrm{C}$ at all times. Next, the hot aliquot was titrated against $0.05 \mathrm{M}$ potassium permanganate oxide until an extremely faint pale pink colour persisted for $15-30 \mathrm{~s}$. Then, the oxalate content was calculated by taking $1 \mathrm{~mL}$ of $0.05 \mathrm{M}$ of potassium permanganate oxide as equivalent to $2.2 \mathrm{mg}$ oxalate (Agbaire, 2011).

\subsubsection{Determination of phytic acid}

Two grams of sample was weighed into a conical flask and soaked with $100 \mathrm{~mL}$ of $2 \%$ hydrochloric acid for $3 \mathrm{hrs}$ and filtered (Whatman No. 4). Next, $25 \mathrm{~mL}$ aliquot of the filtrate was placed in a separate conical flask and $5 \mathrm{~mL}$ of $0.3 \%$ ammonium thiocyanate solution was added. Then, approximately $53.5 \mathrm{~mL}$ of distilled water was added and then was titrated with standard iron (III) chloride solution until brownish yellow colour persisted for 5 mins. Lastly, the phytic acid was calculated using equation 1 (Unuofin et al., 2017):

$$
\text { Phytic acid }(\%)=\text { titrate value } \times 0.00195 \times 1.19 \times 100
$$

\subsubsection{Determination of tannin content}

The tannin was determined by the Folin-Ciocalteu method. One millilitre of the sample extract was added to a volumetric flask $(10 \mathrm{~mL})$ containing $7.5 \mathrm{~mL}$ of distilled water and $0.5 \mathrm{~mL}$ of Folin-Ciocalteuphenol reagent, 1 $\mathrm{mL}$ of $35 \%$ sodium carbonate solution and dilute to 10 $\mathrm{mL}$ with distilled water. The mixture was shaken well and kept at room temperature for 30 mins. A set of reference standard solutions of gallic acid $(20,40,60,80$ and $100 \mu \mathrm{g} / \mathrm{mL}$ ) were prepared in the same manner as described earlier except only $0.1 \mathrm{~mL}$ of gallic acid was used. Absorbance for test and standard solutions were measured against blank at $725 \mathrm{~nm}$ with a UV/Visible spectrophotometer. The tannin content was expressed in terms of $\mathrm{mg}$ of GAE/L of extract. A standard curve was plotted and the tannin content was calculated using the equation from the standard curve.

\subsection{Sensory evaluation}

It is conducted with the purpose to find out the acceptance level of the product among the consumer. The sensory evaluation was carried out by 30 panellists. The master sheet and score sheets for 'Kacang Koro' Energy Bar (KKEB) were prepared using a 7-point hedonic scale which 1 indicates extreme dislike and 7 indicates extreme like. The attributes include colour, sweetness, hardness, taste, bitter aftertaste, and overall acceptability.

\subsection{Statistical analysis}

The statistical comparison was performed with oneway analysis (ANOVA) using Fisher's Least Significant Difference (LSD) test and values of $p<0.05$ were considered significant. The statistical software used to analyze the data is Minitab 19.

\section{Results and discussion}

\subsection{Physical analyses}

\subsection{1 pH analysis}

Table 2 shows the $\mathrm{pH}$ of four 'Kacang Koro' Energy Bar (KKEB) using different types of pre-treatments. The result shows a somewhat significant difference between soaking-boiling and soaking-microwave pre-treatments. The $\mathrm{pH}$ value of KKEB prepared using soaking-boiling pre-treatments exhibited the lowest $\mathrm{pH}$ value to that of the other pre-treatment, which is 5.09. On the other hand, 
Table 2. Physical analysis of 'Kacang Koro' energy bar (KKEB)

\begin{tabular}{lccccc}
\hline Pre-treatments & & Soaking & Soaking + boiling & Soaking + roasting & Soaking + microwave \\
\hline $\mathrm{pH}$ & & $5.28 \pm 0.13^{\mathrm{ab}}$ & $5.09 \pm 0.09^{\mathrm{b}}$ & $5.38 \pm 0.16^{\mathrm{ab}}$ & $5.44 \pm 0.01^{\mathrm{a}}$ \\
\hline \multirow{2}{*}{ Colour } & $\mathrm{L}^{*}$ & $47.35 \pm 4.38^{\mathrm{c}}$ & $54.82 \pm 2.04^{\mathrm{ab}}$ & $59.36 \pm 1.17^{\mathrm{a}}$ & $52.63 \pm 0.54^{\mathrm{b}}$ \\
& $\mathrm{a}^{*}$ & $6.00 \pm 1.27^{\mathrm{a}}$ & $4.81 \pm 0.92^{\mathrm{a}}$ & $5.95 \pm 0.78^{\mathrm{a}}$ & $6.53 \pm 1.66^{\mathrm{a}}$ \\
& $\mathrm{b}^{*}$ & $21.23 \pm 2.13^{\mathrm{a}}$ & $21.38 \pm 1.31^{\mathrm{a}}$ & $22.11 \pm 2.66^{\mathrm{a}}$ & $23.74 \pm 4.62^{\mathrm{a}}$ \\
\hline \multicolumn{2}{l}{ Texture: hardness $(\mathrm{N})$} & $7.17 \pm 0.28^{\mathrm{a}}$ & $6.97 \pm 0.2^{\mathrm{a}}$ & $11.14 \pm 4.09^{\mathrm{a}}$ & $12.71 \pm 4.24^{\mathrm{a}}$ \\
\hline
\end{tabular}

Values with different superscript letters within the column are significantly different $(\mathrm{p}<0.05)$.

the highest $\mathrm{pH}$ for KKEB was illustrated in soakingmicrowave pre-treatments (5.44). The data shows that the $\mathrm{pH}$ value decreased in the order of pre-treatment used namely soaking-boiling $<$ soaking $<$ soaking-roasting $<$ soaking-microwave. The range $\mathrm{pH}$ value of KKEB is between 5.09 and 5.44. However, Silva et al. (2016) showed a higher range of $\mathrm{pH}$ value for their jeriva flour snack bars, which is between 6.78 to 6.92 and it was due to the acidic $\mathrm{pH}$ of jeriva flour itself, which is 4.96 . The KKEB are considered as low-acid food as the $\mathrm{pH}$ is higher than 4.6 (McGlynn, 2003) As the $\mathrm{pH}$ of KKEB in this study is more acidic compared to jeriva flour snack bars, then, it is convinced that it may due to the $\mathrm{pH}$ of raisins and honey as their $\mathrm{pH}$ are range between 3.80 to 4.10 (USFDA, 2019) and 3.20 to 4.66, (Zulkhairi Amin et al., 2018), respectively.

\subsubsection{Colour profile analysis}

Table 2 shows the result for the colour profile of the energy bar using different pre-treated 'Kacang Koro'. The result showed that lightness varies significantly between soaking, soaking-roasting energy bars and soaking-microwave. Nevertheless, it shows no significant difference between the pre-treatments of soaking-boiling and soaking-roasting, and the pretreatments of soaking-microwaving. The value for lightness $\left(\mathrm{L}^{*}\right)$ ranges between 47.35 and 59.36 which represent a slightly darker colour; for the redness $\left(\mathrm{a}^{*}\right)$, the value ranges from 4.81 to 6.53 which shows it is slightly red in colour; and for the yellowness $\left(b^{*}\right)$, the value obtained is from 21.23 to 23.74 which shows that KKEB is yellowish in colour.

Table 2 shows the lowest lightness for the soaking pre-treatments which is 47.35 and the highest lightness for the soaking-roasting pre-treatments which is 59.36 . The lightness value is between 33.62 and 57.49, according to Gir and Mridula (2016), who use the experimental energy bar combined with potato extrudates. It is slightly darker than KKEB, and it has been stated that the increase in the percentage of potato extruders and sweeteners significantly reduces the light energy bar value. In this study, the $L^{*}$ the value of KKEB shows the highest value when using the soakingroasting pre-treatments. Contrary to a study by Ee et al.
(2018), which showed a consequence of roasting various types of beans and decreased the $L^{*}$ value along with the time. They observed the change was due to the loss of surface moisture which decreased the luminosity of the sample (Gowen et al., 2007).

The redness value did not show a significant difference between all KKEB prepared. The soakingmicrowave energy bar has the higher a* value (6.53) suggesting that the sample has more red colour than the others; whereas the lower $\mathrm{a}^{*}$ value is 4.81 when using soaking-boiling process. Based on a study by Srebernich et al. (2016), the results showed $\mathrm{a}^{*}$ values ranging from 7.60 to 11.93 higher than this analysis for their cereal bars. They convinced that the variation of $a^{*}$ and $b^{*}$ value in their samples are due to the level of potato extrudates and sweeteners used in the formulation. The higher $\mathrm{a}^{*}$ values for the previous study compared to this study might be because of the high level of sweeteners used in their formulation, which are up to 45 to $55 \%$ while KKEB only used $25 \%$ of sweeteners (honey and brown sugar) in each of the formulations.

In yellowness value $\left(b^{*}\right)$, it ranges between 21.23 and 23.74, and thus, it showed no significant difference between each sample. The lower $b^{*}$ value (21.23) obtained in the KKEB is when using the soaking pretreatments and the higher one (23.74) is when using the soaking-microwave pre-treatments. The $\mathrm{b} *$ the value for potato extrudates energy bars is between 8.87 to 16.62 which is much lower than this study (Gir and Mridula, 2016). In addition, based on Srebernich et al. (2016), the $b^{*}$ values obtained in their cereal bars (with the addition of acacia gum, inulin, and sorbitol) are ranges between 22.36 to 28.03 , which is quite similar to this study. In another study, the $b^{*}$ values ranged from 20.21 to 40.23 , where the protein bar enriched with Spirulina plantensis was used as samples (Kumar et al., 2018). The higher b* values obtained in this study might be due to the ingredients used such as honey, butter, roasted cashew, and almond. However, the comparison colour within each sample shows somewhat similar profiles; it is believed because of the same ingredients and amount used for each formulation, with only the pre-treatments for 'Kacang Koro' being changed. 


\subsubsection{Texture profile analysis}

Table 2 also shows the Texture Profile Analysis (TPA) of KKEB using different pre-treatment. The result shows the range of the hardness for each of the energy bars is between $7.0 \mathrm{~N}$ and $12.71 \mathrm{~N}$ and the lower value $(7.0 \mathrm{~N})$ is obtained using soaking-boiling pre-treatment while the higher value $(12.7 \mathrm{~N})$ is obtained when using the soaking-microwave pre-treatment. This means that the texture of KKEB is harder when using the soakingmicrowave pre-treatment, while the softer texture is observed when using soaking-boiling. Mridula et al. (2013) stated that the hardness of the energy bar is significantly affected by the level of sweeteners and flaxseed. As the sweetener used for this study is same for all formulations, the softness of the KKEB might be because of the soggy texture that is contributed by the boiling pre-treatment used as it has a higher water absorption capacity (Amon et al., 2014) compared to other pre-treatments.

\subsection{Chemical analyses}

\subsubsection{Proximate analysis}

Table 3 shows the proximate analysis for KKEB using different types of pre-treatment used. The result for moisture content shows a significant difference between all the samples. The moisture content ranges between $8.29 \%$ and $12.42 \%$ with soaking-roasting pre-treatment showed the lowest moisture content among all the samples and the highest moisture content in KKEB is when using the soaking pre-treatment. The lowest moisture content due to the used of the roasting pretreatment is expected by Ee et al. (2018), as similarly studies, who stated that dry heat processing such as roasting may cause alteration in the quality of food materials due to evaporative loss or heat-induced chemical reactions. The highest moisture content was expected in the soaking pre-treatment. Similar results were reported by Doss et al. (2011), who also found that compared to others, the soaking pre-treatment exhibited the highest moisture content, which could be due to the high absorption of water during the process as the was drying procedure was applied onto the soaked pre-treated 'Kacang Koro'. The ash content of all the KKEBs shows no significant difference as the results shown in Table 3 range from $1.09-1.11 \%$. The lower percentage of ash content is when using the soaking-microwave and soaking pre-treatment while the higher percentage is when using the soaking-roasting pre-treatment. The ash content in raw 'Kacang Koro' is $0.94 \%$, however, the previous studies showed the percentage of ash content in 'Kacang Koro' after roasting is 3.6\% (Akanji and Ogungbesan, 2014), and 3.5\% (Agume et al., 2017), which clearly shows an increase of the percentage when using the roasting pre-treatment. Okoye and Eke-Ejiofor (2018) have obtained slightly higher ash content in his energy bar than this study which ranges between $1.54 \%$ and $1.90 \%$ and the energy bar was made of nuts, sesame seeds, and cereals. The ash content $(1.09-1.11 \%)$ is comparable to those reported for 'energy' snack bars containing glutinous rice strips and banana puree as the main ingredient which is $1.13 \%$ (Ho et al., 2016). This indicates that KKEB may contain macrominerals and microminerals as most of the ingredients used such as 'Kacang Koro', and rolled oat which was recorded by many researchers that it has a rich source of essential minerals (Kay, 1979).

Table 3 also showed a significantly different crude protein content between samples using the soakingboiling pre-treatment with the sample using the soakingroasting and soaking-microwave pre-treatment. However, there is no significant difference between samples using the soaking-roasting and soakingmicrowave pre-treatment. The crude protein content of KKEB when using soaking-boiling pre-treatment is the lowest which is $7.51 \%$ and the highest protein content is when using the soaking-microwave pre-treatment which is $10.14 \%$. Oboh et al. (2010), stated that the levels of protein will increase gradually during the roasting process. It is believed that the crude protein is breaking down into smaller polypeptides during processing and it might be the reason for the increment of the total protein content of roasted legume seed. The soaking-boiling pretreatment showed a lower fat content which is $12.75 \%$, while the higher value of crude fat is $17.77 \%$ which is when using the soaking-microwave pre-treatment. As the crude fat content in the soaking pre-treatment is higher

Table 3. Proximate analysis of 'Kacang Koro' energy bar (KKEB)

\begin{tabular}{lcccc}
\hline Treatment & Soaking & Soaking + Boiling & Soaking + Roasting & Soaking + Microwave \\
\hline Moisture & $12.42 \pm 0.39^{\mathrm{a}}$ & $11.95 \pm 0.10^{\mathrm{b}}$ & $8.29 \pm 0.22^{\mathrm{c}}$ & $10.22 \pm 0.33^{\mathrm{c}}$ \\
Ash & $1.09 \pm 0.03^{\mathrm{a}}$ & $1.10 \pm 0.03^{\mathrm{a}}$ & $1.11 \pm 0.12^{\mathrm{a}}$ & $1.09 \pm 0.14^{\mathrm{a}}$ \\
Crude protein & $8.81 \pm 0.49^{\mathrm{ab}}$ & $7.51 \pm 0.71^{\mathrm{b}}$ & $9.95 \pm 0.62^{\mathrm{a}}$ & $10.14 \pm 0.01^{\mathrm{a}}$ \\
Crude fat & $17.02 \pm 0.41^{\mathrm{a}}$ & $12.75 \pm 0.19^{\mathrm{a}}$ & $17.44 \pm 1.37^{\mathrm{a}}$ & $17.77 \pm 4.62^{\mathrm{a}}$ \\
Crude fibre & $2.89 \pm 1.74^{\mathrm{a}}$ & $2.78 \pm 0.67^{\mathrm{a}}$ & $3.35 \pm 0.12^{\mathrm{a}}$ & $3.62 \pm 0.21^{\mathrm{a}}$ \\
Carbohydrate & $56.83 \pm 1.53^{\mathrm{a}}$ & $59.68 \pm 1.34^{\mathrm{a}}$ & $58.41 \pm 2.34^{\mathrm{a}}$ & $57.87 \pm 4.07^{\mathrm{a}}$ \\
\hline
\end{tabular}

Values with different superscript letters within the column are significantly different $(\mathrm{p}<0.05)$. 
than the soaking-boiling pre-treatment, it shows that boiling could reduce the crude fat content in KKEB. This is in close agreement with the finding of Ndidi et al. (2014) who also illustrated a significant reduction of crude fat in the Bambara groundnut when it is boiled. Similar findings were reported by Parreidt et al. (2018), which the boiling treatment decreases the crude fat in the 'Kacang Koro' the most compared to toasting, soaking, and fermentation pre-treatment. Canavalia plagiosperma also showed a reduction of crude fat content when it was boiled (Alagbaoso et al., 2015), as they also convinced that the crude fat content decreased with increased processing time. It could occur due to the fat leaching out into the cooking water as stated by Okaka et al. (1992).

Table 3 also illustrates the crude fibre result for all pre-treatment pre-treatments for KKEB. The soakingmicrowave pre-treatment has a higher value of crude fibre which is $3.62 \%$ and the lower one is when using the soaking-boiling pre-treatment $(2.78 \%)$. The crude fibre content of KKEB using the soaking pre-treatment is reduced to $2.78 \%$ when boiling was performed. In contrast, Doss et al. (2011), who reported that the crude fibre when using the soaking pre-treatment has shown the most reduction of crude fibre in 'Kacang Koro', followed by boiling, and autoclaving pre-treatment. Besides, the crude fibre content in 'Kacang Koro' showed the lowest value $(1.2 \%)$ when using the roasting pre-treatment (the seed was dehulled) in a study by (Agbede and Aletor, 2005). Onyeike et al. (2015) also mentioned that the fibre content in all legumes seeds was decreased throughout the roasting process and it is due to the breaking of bonds between the polysaccharides chains and also the glycosidic linkages in dietary fibre, and this will result in increasing the solubilization of fibre. In contrast, fibre content was increased after going through the roasting process. The crude fibre for "energy" snack energy studied by Ho et al. (2016) showed a lower value compared to this study which is only $1.16 \%$. In comparison, a higher crude fibre content in date bars ranging between $3.56-3.88 \%$ in a previous was reported (Nadeem et al., 2012). In addition Okoye and Eke-Ejiofor (2018), also reported a high crude fibre in their cereal bar made with cereals and nuts with the value ranging from $3.89-6.08 \%$.

\subsubsection{Determination of calorie content}

Table 4 shows the total calorie content in KKEB for each pre-treatment used. The total calorie content ranges between 484.81 (soaking pre-treatment) and the highest calorie content is when using the soaking-microwave pre -treatment $(511.29 \mathrm{kcal} / 100 \mathrm{~g})$. The total energy of cereal bars made from cereals and nuts shows the value ranged from $452.6 \mathrm{kcal}$ to $505.0 \mathrm{kcal}$ (Okoye and Eke-Ejiofor, 2018). Meanwhile, energy bars made from potato extrudates by Gir and Mridula (2016) showed lower calories which is from 332.8 - $343.41 \mathrm{kcal}$. Furthermore, E'zzati (2019) also observed quite similar results with this study which is between $347.8-438.35 \mathrm{kcal} / 100 \mathrm{~g}$. Both these studies used honey as one of the ingredients in developing energy bars. As honey has high carbohydrate content, thus it is an excellent source of energy, and it might contribute to the calorie content of the sample.

\subsubsection{Determination of oxalate content}

Table 5 shows no significant differences in the oxalate content of the pre-treatment pre-treatments used for 'Kacang Koro'. The higher value of oxalate content was observed for the soaking pre-treatment which is 45.1 $\mathrm{mg} / \mathrm{kg}$ while the lower one was the soaking-roasting pretreatment which is $29.81 \mathrm{mg} / \mathrm{kg}$. The trend shows that the oxalate content in 'Kacang Koro' is reduced when treated with the second treatment such as boiling, roasting, and microwave. The reduction of the soakingroasting pre-treatment is $99.25 \%$ while the soaking pretreatment reduces $98.87 \%$ of the oxalate content in 'Kacang Koro'. Adekanni et al. (2009) found that the soaking pre-treatment could reduce oxalate content in Tigernut up to $37-58 \%$. These studies reveal a similar result of this current study where the use of the dry heating method reduced the oxalate content better than the wet method. Compared to previous research, the high reduction in oxalate content may be due to the use of combination pre-treatments in this analysis.

\subsubsection{Determination of phytic acid content}

Table 5 also shows that significant differences in phytic acid content have been observed between 'Kacang Koro' by soaking-boiling pre-treatment, and by the soaking-roasting process, yet there is no significant difference between each pretreatment applied. The lowest phytic acid content was observed in the soakingboiling pre-treatment, which is $0.15 \%$, while the highest phytic acid content in 'Kacang Koro' is $0.37 \%$ when using the soaking-roasting pre-treatment. The trend shows that the percentage of phytic acid increases after going through a roasting and microwave pre-treatment,

Table 4. Calorie content of 'Kacang Koro' energy bar (KKEB)

\begin{tabular}{lcccc}
\hline Pre-treatments & Soaking & Soaking + boiling & Soaking + roasting & Soaking + microwave \\
\hline Calorie $(\mathrm{kcal} / 100 \mathrm{~g})$ & $484.8 \pm 3.50^{\mathrm{c}}$ & $489.3 \pm 15.40^{\mathrm{bc}}$ & $501.6 \pm 8.20^{\mathrm{ab}}$ & $511.3 \pm 2.70^{\mathrm{a}}$ \\
\hline
\end{tabular}

Values with different superscript letters within the column are significantly different $(\mathrm{p}<0.05)$. 
Table 5. Phytochemical analysis of 'Kacang Koro' energy bar (KKEB)

\begin{tabular}{lccccc}
\hline Pre-treatments & Untreated & Soaking & Soaking + boiling & Soaking + roasting & Soaking + microwave \\
\hline Oxalate (mg/kg) & $400 \pm 24.58$ & $45.10 \pm 4.67^{\mathrm{a}}$ & $39.71 \pm 1.71^{\mathrm{a}}$ & $29.81 \pm 5.76^{\mathrm{a}}$ & $37.84 \pm 10.58^{\mathrm{a}}$ \\
Phytic acid (\%) & $2.81 \pm 0.67$ & $0.23 \pm 0.09^{\mathrm{bc}}$ & $0.15 \pm 0.09^{\mathrm{c}}$ & $0.37 \pm 0.04^{\mathrm{a}}$ & $0.34 \pm 0.02^{\mathrm{ab}}$ \\
Tannin (mg GAE/L) & $250.43 \pm 13.57$ & $52.30 \pm 2.95^{\mathrm{a}}$ & $28.76 \pm 15.03^{\mathrm{b}}$ & $25.53 \pm 6.05^{\mathrm{b}}$ & $31.88 \pm 3.54^{\mathrm{ab}}$ \\
\hline
\end{tabular}

Values with different superscript letters within the column are significantly different $(\mathrm{p}<0.05)$.

and reduces when using boiling. In soaking-boiling, wet heat treatment reduces phytic acid better than soakingroasting and soaking-microwaving, which is a wet and dry heat pre-treatment. This data is in concert with Nelson et al. (1978), who stated that wet heat has been proved to produce higher detoxification of ANFs than dry heat. The raw 'Kacang Koro' seed contains $2.81 \%$ of phytic acid. The percentage of phytic acid found in the soaking-boiling process is $0.15 \%$, suggesting a reduction of $94 \%$. In the meantime, for the soaking-roasting process, the level of phytic acid reduction is only $86.7 \%$. The higher reduction in phytic acid when using soakingboiling pre-treatment might be due to phytic acid leaching out into the water (Osman, 2007). Soakingboiling pre-treatment reduced the phytic acid better than the soaking-roasting pre-treatment. This data is in a close agreement with Heleena and Usha (2018) who found that the reduction of phytic acid in maize is higher when using the boiling pre-treatment than when using the roasting pre-treatment. Nelson et al. (1978) also stated that wet heat has been proved to produce higher detoxification of ANFs than dry heat.

\subsubsection{Determination of tannin content}

Table 5 illustrates the raw 'Kacang Koro' seeds containing up to $250.43 \mathrm{mg} \mathrm{GAE} / \mathrm{L}$ of tannins. It can be observed that the tannin content in all of the pretreatment pre-treatments reduced after going through the soaking pre-treatment. The data also shows a significant difference between the soaking and soaking-boiling, and soaking-roasting pre-treatment. The lowest tannin content is when using the soaking-roasting pre-treatment which is $25.53 \mathrm{mg} \mathrm{GAE} / \mathrm{L}$ and the highest tannin content is when using the soaking pre-treatment which is 52.30 $\mathrm{mg} \mathrm{GAE} / \mathrm{L}$. The reduction in tannin was estimated at 99.9\% after soaking-roasting, while soaking could reduce up to $99.8 \%$. This result is in a close agreement with a study conducted by Agume et al. (2017), who used soybean flour as a sample and showed that tannin content decreased generally using the soaking-roasting pre-treatment. It was also shown a similar result in a study by Agume et al. (2016), using 48 hrs of soakingroasting of maize, and the tannin content was reduced by $22 \%$. The data also showed that the tannin content in 'Kacang Koro' in soaking pre-treatment remained higher at double pre-treatment pre-treatments. In addition, Mubarak (2005) has observed a quite lower reduction of tannin in his mung bean which is $39.4 \%$ when soaked in water for $12 \mathrm{hrs}$ at $25^{\circ} \mathrm{C}$. Udensi et al. (2008) also reported that the reduction of tannin content in Mucuna flagellipes is ranged up to $58.4 \%$ to $74.9 \%$ when soaked for 6 to 24 hrs. Based on a study by Abbas and Ahmad (2018), their result has shown that the soaking pretreatment reduced tannin content in various legumes lesser than boiling, extrusion, and microwave pretreatment. The tannin content is found to be reduced when using the soaking pre-treatment. It might be due to diffusion of the ANFs into the soaking water.

\subsection{Sensory evaluation}

Table 6 shows the acceptance of colour of all pretreatment of KKEB demonstrates no significant difference between all samples. The soaking-boiling pretreatment showed higher value compared to that of the other samples. Similar acceptance of colour may have resulted because the substance and quantity used for each sample are identical. The data exhibited that panelists favoured dark brown colour, which was in accordance to the study by Gir and Mridula (2016) who reported that the most preferred energy bar by panelist was the slightly dark in colour with $\mathrm{L}^{*}$ value 51.33 , a* value is 7.11 , and the $b^{*}$ the value is 13.96 . The pretreatment for each sample appears to affect the sweetness acceptance of the KKEB even though the ingredients

Table 6. Sensory evaluation of 'Kacang Koro' energy bar (KKEB)

\begin{tabular}{lcccc}
\hline Attributes & Soaking & Soaking + boiling & Soaking + roasting & Soaking + microwave \\
\hline Colour & $5.3 \pm 1.17^{\mathrm{a}}$ & $5.5 \pm 1.28^{\mathrm{a}}$ & $5.3 \pm 1.17^{\mathrm{a}}$ & $5.3 \pm 1.14^{\mathrm{a}}$ \\
Sweetness & $4.8 \pm 1.64^{\mathrm{b}}$ & $4.8 \pm 1.56^{\mathrm{b}}$ & $5.2 \pm 1.18^{\mathrm{ab}}$ & $5.8 \pm 1.04^{\mathrm{a}}$ \\
Hardness & $4.3 \pm 1.21^{\mathrm{a}}$ & $4.4 \pm 1.22^{\mathrm{a}}$ & $4.4 \pm 1.38^{\mathrm{a}}$ & $4.7 \pm 1.39^{\mathrm{a}}$ \\
Taste & $4.7 \pm 1.36^{\mathrm{b}}$ & $5.1 \pm 1.23^{\mathrm{ab}}$ & $5.2 \pm 1.60^{\mathrm{ab}}$ & $5.5 \pm 1.11^{\mathrm{a}}$ \\
Bitter aftertaste & $5.3 \pm 1.32^{\mathrm{a}}$ & $5.0 \pm 1.35^{\mathrm{a}}$ & $5.2 \pm 1.26^{\mathrm{a}}$ & $5.6 \pm 1.13^{\mathrm{a}}$ \\
Overall acceptability & $4.8 \pm 1.50^{\mathrm{b}}$ & $5.2 \pm 1.19^{\mathrm{ab}}$ & $5.2 \pm 1.27^{\mathrm{ab}}$ & $5.7 \pm 0.95^{\mathrm{a}}$ \\
\hline
\end{tabular}

Values with different superscript letters within the column are significantly different $(\mathrm{p}<0.05)$. 
used for each sample were the same. The boiling and soaking pre-treatment may have a sweeter taste because it can absorb more fluid (from melting sugar, butter, and honey) than the dry heat method, such as roasting and microwave (Amon et al., 2014). There was no significant difference in the acceptability of hardness in which the sample was pre-treated using microwave and soaking treatment. It shows that the panellist preferred the hard energy bar rather than the soft product. Okoye and EkeEjiofor (2018) also showed the result of his most preferred texture acceptability of cereal bars has low moisture content. The lowest acceptability for taste attributes is 4.7, which is KKEB using the soaking process, while the highest acceptability rating for taste of KKEB is 5.5, which is when using the soakingmicrowave technique. There is also no significant difference between the soaking-microwave pre-treatment and the soaking-boiling and the soaking-roasting pretreatment. The high acceptability of taste from the previous study may be attributed to the ingredients used most often by children, such as cornflakes, puffed rice, coconut flakes, etc., as the target consumer is children (Kumar et al., 2018). Table 6 also reveals that the bitter aftertaste attribute indicates no significant difference between each of the samples, yet the lower score was recorded in the soaking-boiling pre-treated samples. The bitter aftertaste may also not be detectable due to sweeteners used in the production of KKEB (Kumar et al., 2018).

\section{Conclusion}

The study shows a significant difference between samples using different pre-treatments for $\mathrm{pH}$, lightness in colour profile analysis, moisture content, crude protein, calorie content, phytic acid content, and tannin content. However, no significant difference was found for $\mathrm{a}^{*}$ and $\mathrm{b}^{*}$ in colour profile analysis, texture profile analysis, ash content, crude fat, crude fibre, carbohydrate, and oxalate content. Sensory evaluation showed that the panels like KKEB the most when using the soaking-microwave pre-treatment based on the overall acceptance. All the pre-treatments used in this study are able to significantly reduce the ANFs content in 'Kacang Koro'.

\section{Conflict of Interest}

The authors declare no conflict of interest

\section{Acknowledgement}

This research was supported by Universiti Malaysia Terengganu. The authors would like to thank the UMT's central lab and FOFIFOS for the facilities provided to conduct the study.

\section{References}

Abbas, Y. and Ahmad, A. (2018). Impact of processing on nutritional and antinutritional factors of legumes: A review. Annals Food Science and Technology, 19 (2), 199-215.

Adekanni, O., Oluwatooyin, O. and Yemisi, A. (2009). Influence of processing technique on the nutrients and antinutrients of Tigernut (Cyperus esculentus L.). World Journal of Dairy and Food Sciences, 4 (2), 88-93.

Agbaire, P.O. (2011). Nutritional and anti-nutritional levels of some local vegetables (Vernomia anydalira, Manihot esculenta, Telfairia occidentalis, Talinum triangulare, Amaranthus spinosus) from Delta state, Nigeria. Journal of Applied Science Environmental Management, 15(4), 625-628.

Agbede, J.O. and Aletor, V.A. (2005). Studies of the chemical composition and protein quality evaluation of differently processed Canavalia ensiformis and Mucuna pruriens seed flours. Journal of Food Composition and Analysis, 18(1), 89-103. https:// doi.org/10.1016/j.jfca.2003.10.011.

Agume, N., Njintang, Y. and Mbofung, C. (2016). Physicochemical and pasting properties of maize flour as a function of the interactive effect of naturalfermentation and roasting. Journal of Food Measurement and Characterization, 11(2), 451-459. https://doi.org/10.1007/s11694-016-9413-1.

Agume, A., Njintang, N. and Mbofung, C. (2017). Effect of soaking and roasting on the physicochemical and pasting properties of soybean flour. Foods, 6(2), 12. https://doi.org/10.3390/foods6020012.

Akande, K.E. and Fabiyi, E.F. (2010). Effect of processing methods on some antinutritional factors in legume seeds for poultry feeding. International Journal of Poultry Science, 9(10), 996-1001. https:// doi.org/10.3923/ijps.2010.996.1001.

Akanji, A. and Ogungbesan, A. (2014). Effects of heattreated Jack beans on the performance characteristics and hematology profile in the commercial broiler. Bangladesh Journal of Animal Science, 43(3), 207212. https://doi.org/10.3329/bjas.v43i3.21650.

Ho, L.-H., Tang, J.Y.H., Mazaitul Akma, S., Mohd Aiman, H. and Roslan, A. (2016). Development of novel "energy" snack bars by utilizing local Malaysian ingredients. International Food Research Journal, 23(5), 2280-2285.

Alagbaoso, S.O., Nwosu, J. N., Umelo, M.C., Eluchie, C. and Agunwa, I.M. (2015). Effect of processing on 
the nutritional and anti-nutritional properties of Canavalia plagiosperma seeds. European Journal of Food Science and Technology, 3(3), 45-69. https:// doi.org/10.1007/s13398-014-0173-7.2.

Aldrich, M. (2015). Inside an energy bar. Retrieved from Experience Life website: https://experiencelife.com/ article/inside-an-energy-bar/

Amon, A., Soro, R., Assemand, E., Due, E. and Kouame, L. (2014). Effect of boiling time on chemical composition and physico-functional properties of flours from taro (Colocasia esculenta cv foute) corm grown in Cote d'Ivoire. Journal of Food Science and Technology, 51(5), 855-864. https://doi.org/10.1007/ s13197-011-0578-7.

AOAC International. (2007). Official Methods of Analysis of AOAC International. AOAC Official Method 990.26. 17th ed. Gaithersburg, MD. USA: AOAC International.

Betancur-Ancona, D., Segura-Campos, M., RosadoRubio, G., Franco, L.S. and Chel-Guerrero, L. (2012). Chemical composition and anti-nutritional factors in five tropical legume seeds. Beans: Nutrition, Consumption and Health, 2012, 117-141.

Doss, A., Pugalenthi, M., Vadivel, V.G.G.S. and Anitha Subash, R. (2011). Effects of processing technique on the nutritional composition and antinutrients content of under - utilized food legume. International Food Research Journal, 18(3), 965970.

Ee, K.Y., Ng, W.J., Cheong, S.M., Soo, C.C. and Yap J.W. (2018). Physicochemical characteristics, antioxidant and antibacterial activities of selected raw and roasted legumes. Food and Nutrition Open Access,1(1), 102.

Eke, C.N.U., Asoegwu, S.N. and Nwandikom, G.I. (2007). Some physical properties of Jackbean seed (Canavalia ensiformis). Agricultural Engineering International: The CIGR Ejournal Manuscript, 9, 07 014.

E'zzati, H.N. (2019). Physicochemical properties and sensory attributes of 'Kacang Koro' and almond energy bar affected by incorporation of different percentages of arabic gum and honey. Terengganu, Malaysia: Universiti Malaysia Terengganu, BSc. Thesis.

Ghadge, P., Vairagar, P. and Prasad, K. (2008). Physical properties of chickpea split (Cicer arietium L.). Agricultural Engineering International: The CIGR Ejournal, 10, 07039.

Gir, N.A. and Mridula, D. (2016). Development of energy bar utilizing potato extrudates. Asian Journal of Dairy and Food Research, 35(3), 241-246. https:// doi.org/10.18805/ajdfr.v3i1.3579

Gowen, A., Abu-Ghannam, N., Frias, J. and Oliveira, J. (2007). Characteristics of cooked chickpeas and soybeans during combines microwave-convective hot air drying. Journal of Food Processing Preservation, 31(4), 433-453. https:// doi.org/10.1111/j.1745-4549.2007.00139.x.

Heleena, J. and Usha, S. (2018). Effect of changes in zinc and phytic acid content in maize under various processes on bioavailability of zinc. International Journal of Current Microbiology and Applied Sciences, 7(12), 1715-1722. https:// doi.org/10.20546/ijcmas.2018.712.199.

Karoli, N., Sumari, J.O. and Marealle, H. (2017). Utilization of Jack Beans (Canavalia ensiformis) for human consumption in Tanzania. International Journal of Agriculture and Food Security, 3(3), 3949.

Kay, E.D. (1979). Crop and product digest No. 3 Food legumes, p. 217-228. London: Tropical products institute.

Kumar, A., Mohanty, V. and Yashaswini, P. (2018). Current research in nutrition and food science development of high protein nutrition bar enriched with Spirulina plantensis for undernourished children. Current Research in Nutrition and Food Science, 6(3), 835-844. http://dx.doi.org/10.12944/ CRNFSJ.6.3.26.

Maphosa, Y. and Jideani, V. (2017). The role of legumes in human nutrition. In Hueda, M.C. (Ed.) Functional Food- Improve Health Through Adequate Food, p. 103-121. InTech Open E-book. https:// doi.org/10.5772/intechopen.69127

McGlynn, W. (2003). The importance of food $\mathrm{pH}$ in commercial canning operations. Retrieved from Oklahoma State University website: https:// extension.okstate.edu/fact-sheets/the-importance-offood-ph-in-commercial-canning-operations.html

Mridula, D., Singh, K.K. and Barnwal, P. (2013). Development of omega-3 rich energy bar with flaxseed. Journal of Food Science and Technology, 50(5), 950-957. https://doi.org/10.1007/s13197-0110425-x.

Mubarak, A. (2005). Nutritional composition and antinutritional factors of mung bean seeds (Phaseolus aureus) as affected by some home traditional processes. Food Chemistry, 89(4), 489495.

j.foodchem.2004.01.007.

Nadeem, M., Anjum, F.M., Murtaza, M.A. and Mueenud-din, G. (2012). Development, characterization, and optimization of protein level in date bars using 
response surface methodology. The Scientific World Journal, 2012, $518702 . \quad$ https:// doi.org/10.1100/2012/518702.

Narang, P. (2017). The truth about energy bar: are they really good for you? Retrieved from NDTV food website: https://food.ndtv.com/food-drinks/the-truthabout-energy-bars-are-they-really-good-for-you1208551.

Ndidi, U.S., Ndidi, C.U., Aimola, I.A., Bassa, O.Y., Mankilik, M. and Adamu, Z. (2014). Effects of processing (boiling and roasting) on the nutritional and antinutritional properties of bambara groundnuts (Vigna subterranea [L.] Verdc) from Southern Kaduna, Nigeria. Journal of Food Processing, 2014, 472129. https://doi.org/10.1155/2014/472129.

Nelson, A., Stein, M. and Wei L.S. (1978). Development of whole soybean food for home use: Rationale, concept and examples. International soybean programme (INSOY). Urbana, IL, USA: College of Agriculture, University of Illinois.

Oboh, G., Ademiluyi, A. and Akindahunsi, A. (2010). The effect of roasting on the nutritional and antioxidant properties of yellow and white maize varieties. International Journal Food Science and Technology, 45(6), 1236-1242. https:// doi.org/10.1111/j.1365-2621.2010.02263.x.

Okaka, J., Akobundu, E. and Okaka, A. (1992). Human nutrition: an integrated approach. $2^{\text {nd }}$ ed., p. 355-375. Enugu, NIgeria: OcJanco Academic publishers.

Okoye, J. and Eke-Ejiofor, J. (2018). Nutrient composition, lipid profile and sensory properties of cereal bar made from locally available cereals and nuts. International Journal of Biotechnology and Food Science, 6(1), 1-8.

Onyeike, E., Anyalogbu, E. and Monanu, M. (2015). Effect of heat processing on the proximate composition and energy values of African walnut (Plukenetia conophora) and African elemi (Canarium schweinfurthii) consumed as masticatories in Nigeria. International Journal Science Technology Research, 4(8), 295-301.

Osman, M.A. (2007). Effect of different processing methods on nutrient composition, anti-nutritional factors and in vitro protein digestibility on Dolichos lablab bean (Lablab purpureus (L) sweet). Pakistan Journal of Nutrition, 6(4), 299-303. https:// doi.org/10.3923/pjn.2007.299.303.

Parreidt, T.S., Schott, M., Schmid, M. and Müller, K. (2018). Effect of presence and concentration of plasticizers, vegetable oils, and surfactants on the properties of sodium-alginate-based edible coatings. International Journal of Molecular Sciences, 19(3),
1-21. https://doi.org/10.3390/ijms19030742.

Silva, E.P.D., Siqueira, H.H., Damiani, C. and Vilas Boas, E.V.D.B. (2016). Physicochemical and sensory characteristics of snack bars added of jerivá flour (Syagrus romanzoffiana). Food Science and Technology, 36(3), 421-425. https:// doi.org/10.1590/1678-457x.08115.

Srebernich, S.M., Gonçalves, G.M.S., Ormenese, R.D.C.S.C. and Ruffi, C.R.G. (2016). Physicochemical, sensory and nutritional characteristics of cereal bars with addition of acacia gum, inulin and sorbitol. Food Science and Technology, 36(3), 555562. https://doi.org/10.1590/1678-457x.05416.

Uadia, N. (2017). Preliminary studies on Canavalia ensiformis (Jackbean) Dc. Seeds: proximate analysis and phytochemical screening. Science World Journal, 12(2), 59-62.

Udensi, E.A., Arisa, N.U. and Maduka, M. (2008) Effect of processing methods on the levels of some antinutritional factors in Mucuna flagellipes. Nigerian Food Journal, 26(2), 53-59.

Uma, G., Alla, M. and Jithendran, L. (2018). Development and analysis of nutri bar enriched with zinc for sports athletes. International Journal of Advanced Research in Science, Engineering and Technology, 5(4), 5558-5570.

Unuofin, J.O., Otunola, G.A. and Afolayan, A.J. (2017). Essential oil composition, nutrient and anti-nutrient analysis of Vernonia mespilifolia less. Research Journal of Botany, 12(2), 38-45. https:// doi.org/10.3923/rjb.2017.38.45. 